\title{
An Empirical Study on Market Reaction around the Bonus Issues Announcements in Bangladesh
}

\author{
A. F. M. Mainul Ahsan ${ }^{1}$, Muhammed Ashadur Rahman Chowdhury ${ }^{2} \&$ Ahasan Habib Sarkar $^{3}$ \\ ${ }^{1}$ Lecturer, School of Business, Independent University, Bangladesh \\ ${ }^{2}$ BBA Student, Independent University, Bangladesh \\ ${ }^{3}$ Master of Commerce Candidate, The University of Sydney, Australia \\ Correspondence: A. F. M. Mainul Ahsan, School of Business, Independent University, Bangladesh. Tel: \\ 880-171-7012-818. E-mail: mainul188@gmail.com
}

Received: October 1, $2013 \quad$ Accepted: November 6, $2013 \quad$ Online Published: December 23, 2013

doi:10.5539/ijef.v6n1p82 URL: http://dx.doi.org/10.5539/ijef.v6n1p82

\begin{abstract}
The objective of this study is to examine the stock price reaction to the bonus issue announcement in Dhaka Stock Exchange (DSE) in Bangladesh. Data of all the 136 right issues from six different sectors, i.e., Engineering, Cement, Food \& Allied, Fuel \& Power, Pharmaceuticals \& Chemicals, and Textile during 2009 to 2012 combined with the standard event study methodology has been used for this purpose. Findings reveal statistically significant abnormal returns on and around the bonus issue announcement dates which supports signaling hypothesis for Bangladesh and also implies that investors have anticipated the informational content of the event, or that they have gained access to inside information. However, sectoral decomposition of returns showed quite paradoxical results. Cement, Food \& Allied, Fuel \& Power, and Pharmaceuticals \& Chemicals sector supports long-established theories that the stock market reacts positively to the announcement of a bonus issue. However, Engineering and Textile sector illustrates the opposite. Results of this study imply that DSE is not semi-strong form efficient with respect to past information on bonus issue announcements. Also, information leakage before the announcement of bonus issues raises serious questions against efficiency in regulation and effectiveness of supervision in DSE.
\end{abstract}

Keywords: bonus issues, announcement date, abnormal returns, event study

\section{Introduction}

Bonus issues are basically distributions of additional stocks to existing stockholders with out an alteration in the financial position of the firm or its shareholders. Accordingly, they result in each shareholder holding a greater number of shares, but their relative claim on the assets of the company stays the same. A company can distribute bonus shares by using retained profit or accumulated capital reserves. Listed firms in Bangladesh usually prefer to issue bonus shares from the accumulated capital reserves, or from a combination of capital reserves and retained earnings. Bonus share issues are equivalent to stock dividends in the United States and scrip issues in the United Kingdom. Based on the charter of the firm, only certain categories of shares may be entitled to stock dividend, or may be allowed to bonus issues prior to other classes.

Issuing bonus shares can also be described as conversion of profit into share capital or capitalization of profits, that is, converting reserve or profits into paid up capital. A firm may capitalize its profits or reserves, which otherwise can be distributed as dividends among shareholders, by: (1) Converting partially paid stocks into wholly paid by announcing stock dividend without asking shareholders to pay for the same; and (2) Issue of entirely paid stocks as bonus shares to the existing shareholders.

In addition, as per the income tax regulation, shareholders in Bangladesh need to pay tax for the cash dividend but not for the stock dividend which makes the bonus shares even more attractive. However, this does not mean that the shareholders in Bangladesh hail all the bonus offerings. Also, low ratio bonus may not convey the same informational contents as the high ratio bonus issues.

Miller and Modigliani (1961) reported that bonus offerings, along with other types of dividends, do not change shareholders' wealth. If a firm decides to realize a bonus issue from retained earnings, it creates a book entry to adjust retained earnings into paid-up capital in the shareholders' equity section of the company balance sheet. 
Alternatively, a company that intends to finance a bonus issue by using accumulated capital reserves allocates the accumulated capital reserves into paid-up capital. In both ways, bonus issuing firm does not receive any cash and its financial position remains unchanged. The adjustment caused by the bonus offerings is that the number of outstanding shares is modified by the bonus issue ratio, consequently, the price of the shares drops in relation to the same bonus issue proportion. The total market value of the firm or the values of the stocks that are held by each investor remain constant. Following the above rationale, Sloan (1987) provided evidence from Australian market that bonus issues do not affect shareholders' wealth.

However, in practice there may be an increase in stock price following the declaration of stock dividend. This price hike can happen because the declaration of a bonus issue may have beneficial information content (Peterson, 1971). After the bonus issue, it has been noticed that, firms usually raise dividends per share above the extent to maintain the same total dividend payout which indicates positive confidence of management about the firm's future. As a result, the stock price may soar in reaction to this information. The informational connection between dividends and earnings is also empirically established in Healy and Palepu (1988) work. They reported that companies that start stock dividends experience significant growth in earnings for at least one year after the declaration.

Also, the presence of significant abnormal returns occurring before and after the announcement date implies that the investors have predicted the informational content of the event, or that they have accessed to inside information. The occurrence of significant non-zero abnormal returns with the same sign on and after the announcement date indicates systematic under-reaction of the stock prices in response to the information. In contrast, different sign of the significant non-zero abnormal returns on and after announcement date imply overreaction. Where there is no under-reaction or overreaction, a significant and abnormal performance of stock prices on the event announcement date is consistent with the hypothesis that stock prices fully, instantly and correctly reflect the announced information.

Section 2 of this paper lists some relevant previous studies, section 3 talks about some existing works that explain stock price behavior after bonus stock offerings, Section 4 describes data collection, section 5 defines models employed in this study, section 6 discusses results of the research and lastly, and finally, section 7 provides concluding remark on the study.

\section{Literature Review}

There is mixed evidence regarding the stock market reaction to bonus issue announcement. Researchers have illustrated earlier that the market generally reacts positively to bonus issue announcement. Peterson (1971), Ball, Brown and Finn (1977), Foster and Vickrey (1978), Woolridge (1983), Grinblatt, Masulis and Titman (1984), Healy and Palepu (1988), Lamoureax and Poon (1987), Ikenberry, Rankine and Stice (1996), Ramachandran (1985), Lijleblom (1989), McNichols and Dravid (1990), Obaidullah (1992), Rao (1994), Masse, Hanrahn and Kushner (1997), and Anderson, Cahan and Rose (2001) shown positive market reaction to bonus issue announcement. However, Malhotra, Thenmozhi and Gopalaswamy (2012), Papaioannou, Travlos and Tsangarakis (2000), and Dhatt, Kim and Mukherji (1997) have found the reaction to be negative.

Using monthly data, Ball, Brown and Finn (1977) investigated share price reaction around the announcement of 'share capitalization changes' because of bonus share issues, share splits and rights issues in Australia for the period between 1960 and 1969. While they reported 20.2 percent excess return, they failed to provide any statistically significant evidence of price response during declaration period.

Grinblatt, Masulis, and Titman (1984) examined the announcement effect of stock dividends and splits of NYSE and AMEX listed securities from 1967-1976. They noted that equity prices usually respond positively to stock dividend and stock split announcements which are not contaminated by other contemporaneous firm-specific declarations. Besides, they documented significant positive abnormal returns on and around the ex-date of bonus issue and splits. However, announcement and ex-date returns were found to be higher for bonus issues comparing to stock splits. They concluded that both stock dividends and splits signals about the future cash flows even when cash dividend is absent.

Lijleblom (1989) investigated the signaling hypothesis of scrip issues and stock splits for the firms listed with the Stockholm Stock Exchange. In their sample, in 90 percent of the cases, scrip issues and stock splits announcements were contaminated by the simultaneous announcements of other material information. The impact contemporaneous declarations of other material information are controlled by using a control group of otherwise similar stocks but which do not split or distribute a stock dividend. They found notably greater price reactions for the scrip issues and split group than the control group which is taken as evidence for the signaling hypothesis in the presence of contaminating announcements. 
McNichols and Dravid (1990) provided additional evidence to support the signaling hypothesis by examining the relationship between the size of a bonus issue and the degree of abnormal returns around the announcement dates. Their findings showed a positive relationship between stock dividend size and abnormal return, i.e., the larger the stock dividend, the greater the signaling benefits.

Rao and Geetha (1996) estimated average cumulative abnormal return of 6.31 percent around the three days of the announcement of bonus which aided them to conclude that the capital market is not inherently a semi-strong form of EMH.

Investigating the impact of stock dividend announcements on the value of firms listed on the Toronto Stock Exchange, Masse, Hanrahn and Kushner (1997) found significant positive abnormal returns around the announcement date.

Barnes and Ma (2001) employed event study methodology to examine share price response to the declaration of stock dividend in China. Results exhibit that issues with a higher stock dividend usually attract positive returns and stocks with a lower stock dividend are rewarded with negative returns. The A-shares' and B-shares' prices in China show some similarities in their response to bonus issues announcements.

Balasingham, Faff and Tanner (2004) investigated share price reaction to the announcement of stock dividends of Australian firms. Using market model and data for the period of January 1992 to December 2000, they found that price reaction to bonus issue announcements from day 0 to day 1 is significantly positive 2.37 percent for uncontaminated events and 2.11 percent for contaminated events. They also found price reaction to bonus issue announcements is significantly stronger for industrial non-financial and mining companies than financial companies. Their study also detected pre-announcement effect only for industrial non-financial and financial companies that announced stock dividend simultaneously with other market sensitive information such as interim or final results.

Rao and Lukose (2005) investigated the operating performance of firms listed with the Bombay Stock Exchange subsequent to stock dividend payments. They found that these firms exhibit superior performance compared to control firms matched on the basis of industry and size and to another set of control firms based on industry and pre-event performance. They observed statistically significant positive abnormal return of 11.60 percent for five days starting from day-3. Their further analysis reveals considerable difference in the operating performance and announcement return across firms belonging to different ownership groups.

Using event study methodology for a sample of 46 bonus issues for the period of June 1998 to August 2004, Mishra (2005) studied the share price response to the information content of stock dividend to examine whether the Indian stock market is semi-strong efficient or not. He computed significant positive abnormal returns on and for a five-day window prior to bonus announcement which questions semi-strong efficiency of the Indian stock market.

Pathirawasam (2009) also employed event study methodology to examine the stock price reaction to stock dividends announcements in Sri Lankan from 1998 to 2007. The amount of positive abnormal returns on the announcement day in Colombo Stock Exchange is much larger comparing to any other international discoveries. Even after controlling for contemporaneous announcements of other material information, abnormal returns for pure stock dividends are positively significant on the declaration day. He also found that announcement day (i.e., $\mathrm{t}=0$ ) abnormal returns increases with the size of the stock dividend and vise-versa.

However, a study in U.S. by Papaioannou, Travlos and Tsangarakis (2000) analyzing price reaction to stock dividend announcements by firms listed on the Athens Stock Exchange found no statistically significant abnormal returns on and around the announcement date. The results of this research can be explained by the fact that most stock dividend distributions are compulsory requirements imposed upon the firms to satisfy regulatory requirements and shareholder approval must be sought regarding the size and terms of the distributions.

Even though most of the papers have tried to explain changes in abnormal returns and cumulative abnormal returns, very few authors have extended the study to identify whether the size of the bonus issue, the market value of firm, book to market ratio and the pre cumulative abnormal returns contribute to the abnormal returns observed around bonus issue announcement. For example, Adaoglu and Lasfer (2011) studied the market valuation of stock dividends which were funded by the revaluations of reserves in an inflationary environment and found positive abnormal return on the declaration day for these stock dividends in Turkey.

\section{Theories that Explain Stock Price Behavior after Bonus Stock Offerings}

Even though issuing of bonus share magnifies the total number of stocks issued and outstanding, it does not impact value of the firm, and also the percentage of shares owned by each shareholders remains the same. 
However, it is quite paradoxical that even though stock dividend increases number of shares outstanding, market reacts positively to the announcement of a bonus issue. Some theories that attempts to explain stock price behavior after bonus issue announcements is discussed in the below.

Empirical research has shown that the stock prices usually react positively to the declaration of a stock dividend. While several hypotheses have been advanced to dig down into this phenomenon, signaling hypothesis has received the strongest support in clarifying the positive market response to bonus issue declarations (U.S.Foster \& Vickrey, 1978; Woolridge, 1983; Grinblatt, Masulis, \& Titman, 1984; Canada-Masse, Hanrahn, \& Kushner, 1997; New Zealand-Anderson, Cahan, \& Rose, 2001; Sweden-Lijleblom, 1989; India-Rao, 1994). Signaling hypothesis suggests that the declaration of stock dividend conveys new information to the market in instance where managers have asymmetric information. This theory has received explicit support with few exceptions, for instance, Papaioannou, Travlos and Tsangarakis (2000).

Grinblatt, Masulis and Titman (1984) offered the attention getting hypothesis indicating that managers use bonus issue to draw attention from analysts to re-evaluate their future cash flows. Doran and Nachtmann (1988) studied the attention getting hypothesis and found that immediately after the announcement of a stock dividend there was a significant positive revision in analyst's earnings expectations, which they interpreted as support for the attention getting hypothesis.

Lakonishok and Lev (1987) investigated the Liquidity hypothesis, which suggests that stock dividend announcements are indented to improve liquidity, as the creation of additional stocks should lead to an increase in trading and greater ownership dispersion in a firm.

Ghosh and Woolridge (1988) noticed that negative stock price reaction to dividend drops can be compensated by offering a stock dividend as a substitute. This finding lends support to the cash substitution hypothesis, which suggests that firms save cash by issuing bonus share as an interim substitute for a cash dividend. Banker, Das and Datar (1993) examined the cash substitution hypothesis by investigating the stock price response to companies who declared they were suspending cash dividends, but going to maintain current level of stock dividends. They found an insignificant positive excess return followed these announcements. Banker, et al. (1993) also found that firms with no prior stock dividend history who announced that they were discontinuing cash dividends experienced significantly negative share price reactions, supporting the cash substitution hypothesis. Kato and Tsay (2002) provided empirical evidence in favor of the cash substitution hypothesis as well as signaling hypothesis for Japan.

Eisemann and Moses (1978) studied managements' reactions toward stock dividends. They found that firms offer stock dividends mainly because of historical company practice and cash conservation. They also noticed that terminating an existing policy of issuing bonus shares would result in adverse market reactions.

\section{Data}

The sample in this paper includes 136 firms from six different sectors, i.e., Engineering, Cement, Food \& Allied, Fuel \& Power, Pharmaceuticals \& Chemicals, and Textile, from Dhaka Stock Exchange (DSE) which have declared stock dividend from 2009 to 2012. Only those stocks whose return is available for at least 90 days prior to 30 days after the announcement date are included in this sample. Sectoral distribution of all the 136 sample securities that issued bonus shares during the sample period is presented in table 1.

Table 1. Sample distribution of samples according to sectors (2009-2012)

\begin{tabular}{lccccc}
\hline \multicolumn{1}{c}{ Sector } & $\mathbf{2 0 0 9}$ & $\mathbf{2 0 1 0}$ & $\mathbf{2 0 1 1}$ & $\mathbf{2 0 1 2}$ & Total \\
\hline Engineering & 9 & 5 & 7 & 8 & 29 \\
Cement & 4 & 4 & 3 & 5 & 16 \\
Food \& Allied & 3 & 1 & 4 & 2 & 10 \\
Fuel \& Power & 4 & 5 & 5 & 6 & 20 \\
Pharmaceuticals \& Chemicals & 8 & 8 & 4 & 10 & 30 \\
Textile & 4 & 12 & 5 & 10 & 31 \\
Total & $\mathbf{3 2}$ & $\mathbf{3 5}$ & $\mathbf{2 8}$ & $\mathbf{4 1}$ & $\mathbf{1 3 6}$ \\
\hline
\end{tabular}

DSE All Share Price index (DSI) is employed as the proxy for the market portfolio. DSI, a capitalization-weighted index, consists of all the companies listed with the DSE, or more specifically, Z category 
share are also included in the DSI. The information about individual firm's security return, market return, the companies issuing bonus shares, and their announcement dates are obtained from the DSE library.

In order to find the price reaction to the announcement of bonus shares in Bangladesh, cross sectional Cumulative Abnormal Average Return (CAAR) was computed for the 136 samples over the period of 121 days.

\section{Model and Construction of Variables}

To examine the market response to stock dividend announcement, Bowman (1983) and Brown \& Warner (1980; 1985) standard event study methodology is used. In order to construct an event study, the event, event date, event window, estimation window and estimation model should be established. The event is what the researcher would like to investigate. The events employed for this paper are the declarations of bonus issue. The events have been studied in relation to share price reaction. The event date is the date of announcement of bonus issue by the sample firms. It can be expressed as $t=0$.

If rumors about the bonus share issue start before the announcement date, it is likely to see the price movement prior to $t=0$. Therefore, the starting point of the event windows is taken $t-30$. It is important to open the event window prior to the event date, since it provides an indication about information leakage prior to the announcement, and thus effectiveness of regulation and supervision. Table 2 shows the event windows that are opened in this study. In addition to $(-30,30)$, there are five other event windows which are specified in the first column. This Table also shows the reasons for opening the event windows and possible implication of it.

Table 2. Reason for opening and implications of event windows

\begin{tabular}{lll}
\hline Event windows & Reasons for opening window & Implications \\
\hline CAAR $(-10,-1)$ & To test information leakage & Efficiency in regulation and effectiveness of \\
CAAR $(-5,-1)$ & & supervision \\
CAAR $(0,1)$ & To test announcement effect of dividend and & Information content of dividend and \\
CAAR $(0,5)$ & market efficiency & duration of price adjustment \\
CAAR $(0,10)$ & & \\
\hline
\end{tabular}

It is commonly expected that the price adjustment takes place on $t=0$ in an efficient market. It is crucial for the end of event window a few days after the event day to study more about market efficiency and the duration of price adjustment. In thin and inefficient markets, the price adjusts more slowly than in deep and efficient markets. Thus, the event window for this study is 30 days before and 30 days after bonus share issue. It can be expressed as -30 to +30 . Within $t-30$ to $t+30$ alternative event windows are also used to observe the price effect.

The estimation period is the time window preceding the occurrence of the above mentioned event. Usually estimation period and event windows are chosen in such a way so that they do not coincide. The estimation window in this study is 90 days prior to 31 days ahead of the event date. It can be expressed as $t=-90$ to $t=-31$.

The selected examination model for this study is Sharpe's (1963) Single Index Model or simply the market model. The model assumes that the return on an asset is determined by a constant and the return to the market portfolio.

Actual return on security $j$ in period $t$ is calculated as below. However, dividend has not been considered during calculating stock return.

$$
R_{j t}=\frac{P_{j t}-P_{j t-1}}{P_{j t-1}}
$$

Where,

$P_{j t}=$ Price of security $j$ on day $t$; and $P_{j t-1}=$ Price of security $j$ on day prior to day $t$.

In this study, the market adjusted return model is used to estimate the abnormal return. However, some studies used the market risk adjusted model. In market adjusted model, the beta coefficient is 1 and the intercept term is considered to be zero. Conversely, beta coefficient is computed by regression analysis in the market risk adjusted model. Marsh (1979) mentioned that due to the data limitation the risk adjusted model lessens statistical efficiency. Armitage (1995), Brown and Warner (1980) argued that the market risk adjusted model is not superior to the market adjusted model. However, in case of small markets, the market adjusted model delivers results as 
acceptable as the risk adjusted model.

Expected return on security $j$ in period $t$ is computed using Sharpe's (1963) following Single Factor model:

$$
E R_{j t}=R_{m t}+\mu_{j t}
$$

Where,

$R_{m t}=$ The rate of return on market index, DSI in this case, on the day $t$; and

$\mu_{j t}=$ Error term which is assumed to be independent and identically distributed.

For the purpose of studying the impact of bonus share issues on share prices abnormal returns are computed. Abnormal returns are calculated by deducting expected returns of security $j$ on day $t$ from the actual returns of the same security $j$ on day $t$. The following equation is applied for computation of abnormal return for a specific security:

$$
A R_{j t}=R_{j t}-E R_{j t}
$$

Where,

$A R_{j t}=$ Abnormal return of security $\mathrm{j}$ on day $t$;

$R_{j t}=$ Actual return on security $\mathrm{j}$ on day $t$; and

$E R_{j t}=$ Expected return on security $\mathrm{j}$ on day $t$.

After calculation of abnormal returns of all the securities, the average abnormal returns (AARs) are computed during event period $(-30$ to +30$)$. AARs are estimated as below:

$$
A A R_{t}=\frac{1}{N} \sum_{j=1}^{N} A R_{j t}
$$

Where,

$A A R_{t}=$ Average of abnormal return for day $t$; and

$N=$ Number of securities in the sample, i.e., 136 in this study.

The abnormal returns are summed up trading day-wise and then divided by number of securities, i.e., 136 in this study. Thus, cross-sectional and time-series aggregation is done to calculate cumulative average abnormal return $\left(C A A R_{t}\right)$ using the following formula:

$$
\operatorname{CAAR}\left(\mathrm{t}_{1}-\mathrm{t}_{2}\right)=\sum_{i=t_{l}}^{t_{2}} A A R_{i}
$$

Ritter (1991), Barber \& Lyons (1997), and Lyon, Barber, \& Tsai (1999) have argued that CAARs are not appealing on economic grounds. However, Barber and Lyons (1997) argued that for short horizons, both CAAR and BHAR are very similar.

$T$-test is used to determine the statistical significance of $C A A R_{t}$ and $A A R_{t}$. For computation of $t$-scores the aggregate pre-event standard deviation of abnormal returns of all the securities is computed. Individual company's pre-event standard deviation (i.e. from -90 to -31 ) is computed and then aggregation is done. The formula for estimation of pre-event standard deviation of daily abnormal returns is given in the below:

$$
\sigma_{i, p r e}=\sqrt{\frac{\sum_{-90}^{-31}\left(A R_{j t}-A A R_{p r e}\right)^{2}}{n}}
$$

Where,

$\sigma_{i, p r e}=$ Standard deviation of abnormal returns for security $i$ estimated from the pre-event measurement period; $n=$ Number of days in pre-measurement period; and

$A A R_{\text {pre }}=$ Average abnormal return for security $i$ estimated from pre-event measurement period.

Aggregate pre-event standard deviation is computed as follows:

$$
\sigma_{N, p r e}=\sqrt{\frac{\sum_{i=1}^{N} \sigma_{i, p r e}^{2}}{N^{2}}}
$$


$\sigma_{\mathrm{N}, \text { pre }}$ is applied on AAR of each day. The t-test for AARs is as follows:

$$
A A R_{t} \text { t-stat }=\frac{A A R_{t}}{\sigma_{N, \text { pre }}}
$$

For testing CAARs, The t-test formula is:

$$
C A A R_{t} \quad t \text {-stat }=\frac{C A A R_{t}}{\sigma_{N, \text { pre }} \sqrt{N_{t+1}}}
$$

Where $N_{t+1}=$ the absolute value of event day $t$ plus 1 (e.g., for event day -10 , the absolute value is 10 and $N_{t}=10$ and thus $N_{t+1}=11$. A testable hypothesis is set as below:

$H_{0}$ : The null hypothesis being tested is that abnormal returns on and around the bonus share announcements are less than or equal to zero.

If $A A R_{t}$ or $C A A R_{t}$ are larger than zero and statistically significant, it indicates that the stock prices on an average reacted positively to the stock dividend. Thus lead to increase the wealth of shareholders. If the $t$-score is larger in absolute value than 1.960 or 2.576 , the relevant abnormal return is statistically non-zero at $5 \%$ or $1 \%$ significance level respectively.

\section{Results and Analysis}

Table 3 presents summary statistics for the whole sample period. Food \& Allied sector delivered the maximum average abnormal return (AAR), i.e., $\approx 0.16$ percent, while Textile presented the lowest average abnormal return i.e., -0.10 percent, during the whole sample period. The AAR for the entire period by the whole sample is -0.02 percent. It worth mentioning that there was a massive market crash in Bangladesh in 2010 which hammered down this market return. Market was at its peak on December 5, 2010 when DGEN index was 8771.41. However, on July 18, 2013 the same index reached to 4568.47, i.e., 47.92 percent decline from the market peak. Whole sample and also all the sectoral abnormal returns, except Pharmaceuticals \& Chemicals sector, exhibit negative skewness, i.e., data are skewed to the left. Abnormal return data of all the sample sectors excluding the textile sector kurtosis greater than three which represents leptokurtic distribution, i.e., flatter tails than the normal distribution. However, AAR provided by Textile has kurtosis less than three, i.e., platykurtic. Even the whole sample has kurtosis less than three, i.e., flatter peak comparing to the normal distribution. Food \& Allied not only delivers highest abnormal return, it also exhibits highest volatility measured by standard deviation.

Table 3. Descriptive statistics of average abnormal returns (AAR)

\begin{tabular}{lccccccc}
\hline & Total & Engineering & Cement & $\begin{array}{c}\text { Food } \\
\text { \&Allied }\end{array}$ & $\begin{array}{c}\text { Fuel \& } \\
\text { Power }\end{array}$ & $\begin{array}{c}\text { Pharmaceuticals } \\
\text { \& Chemicals }\end{array}$ & \begin{tabular}{c} 
Textile \\
\hline Mean
\end{tabular} \\
\hline Standard Error & $-0.02 \%$ & $-0.03 \%$ & $-0.04 \%$ & $0.16 \%$ & $-0.06 \%$ & $0.07 \%$ & $-0.10 \%$ \\
Median & $0.04 \%$ & $0.10 \%$ & $0.11 \%$ & $0.13 \%$ & $0.09 \%$ & $0.08 \%$ & $0.10 \%$ \\
Std. Deviation & $0.47 \%$ & $0.11 \%$ & $0.06 \%$ & $0.12 \%$ & $0.02 \%$ & $0.03 \%$ & $-0.05 \%$ \\
Kurtosis & 1.92 & $6.11 \%$ & $1.26 \%$ & $1.43 \%$ & $1.02 \%$ & $0.87 \%$ & $1.05 \%$ \\
Skewness & -0.91 & -0.52 & 7.83 & 11.19 & 6.37 & 14.12 & 2.78 \\
Minimum & $-1.80 \%$ & $-4.27 \%$ & $-6.10 \%$ & $-8.65 \%$ & $-5.04 \%$ & $-2.45 \%$ & -1.04 \\
Maximum & $1.04 \%$ & $5.16 \%$ & $2.81 \%$ & $3.64 \%$ & $2.23 \%$ & $5.65 \%$ & $2.40 \%$ \\
\hline
\end{tabular}

For each of the 61 days in the experimental period table 4 to table 10 reports the daily Average Abnormal Returns (AARs) for days $t-30$ to $t+30$ along with the $t$-statistics to tests the null hypothesis. The first column in the table presents the event day while the second gives the average abnormal returns on the corresponding event day. The $t$-statistics corresponding to the AARs are given in the third column. Column 4 shows Cumulative Average Abnormal Returns (CAARs). Last column shows $t$-scores for CAAR.

Table 4 presents the empirical results of the entire sample consisting of 136 bonus issues from 6 different sectors in the DSE. Right before the announcement date, for a short span of time, $t-4$ to $t=0$, a consistent pattern of abnormal daily returns is observed, i.e., AAR is negative. The AARs before the announcement period ( -30 to -1 day) are positive only for 19 days out of 30 days and are negative for rest of the 11 days. For observations before the announcement date, no significant abnormal return is observed. The AARs after the announcement date show no consistent pattern. After the announcement date for 15 days there were positive returns and for rest of the days there were negative returns. After the announcement date, AARs are significant at $5 \%$ level only on day $t+1$, $t+14$ and on $t+16$. 
The analysis of CAAR in table 4 also shows that during pre-event window CAAR for all the 30 days was positive, indicating the optimistic reaction of the market in anticipation to stock dividend. When whole sample period is considered, we observe that CAARs start to pick up on day $t+1$, and increases to $3.36 \%$ on day $t+6$. On announcement day there was a decrease in CAAR from 1.57 percent to 1.29 percent. After the event date CAAR is positive until day $t+15$. Most importantly, a consistent pattern in CAAR is observed. From day $t-17$ to $t+9$, i.e., for 27 days, statistically significant CAAR has been detected which supports the signaling hypothesis. However, the presence of significant abnormal returns occurring before and after the announcement date implies that the investors have anticipated the informational content of the event, or that they have accessed to inside information in Dhaka Stock exchange (DSE).

Table 4. Daily AARs, CAARs, \& Respective t-test statistics for the entire sample

\begin{tabular}{|c|c|c|c|c|c|c|c|c|c|}
\hline $\mathbf{T}$ & AAR & $\begin{array}{l}t \text {-test } \\
\text { (AAR) }\end{array}$ & CAAR & $\begin{array}{l}t \text {-test } \\
\text { (CAAR) }\end{array}$ & $\mathbf{T}$ & AAR & $\begin{array}{l}t \text {-test } \\
(\mathbf{A A R})\end{array}$ & CAAR & $\begin{array}{l}\text {-test } \\
\text { (CAAR) }\end{array}$ \\
\hline-30 & 0.008 & 1.73 & 0.008 & 0.31 & 1 & 0.009 & $2.02 * *$ & 0.022 & $3.49 * * *$ \\
\hline-29 & 0.002 & 0.42 & 0.010 & 0.39 & 2 & -0.002 & -0.49 & 0.020 & $2.57 * *$ \\
\hline-28 & 0.001 & 0.27 & 0.011 & 0.45 & 3 & 0.006 & 1.34 & 0.026 & $2.90 * * *$ \\
\hline-27 & -0.001 & -0.16 & 0.010 & 0.43 & 4 & 0.008 & 1.71 & 0.033 & $3.36 * * *$ \\
\hline-26 & 0.004 & 0.97 & 0.014 & 0.62 & 5 & 0.004 & 0.91 & 0.037 & $3.44 * * *$ \\
\hline-25 & 0.003 & 0.75 & 0.018 & 0.78 & 6 & 0.002 & 0.38 & 0.039 & $3.33 * * *$ \\
\hline-24 & 0.004 & 0.97 & 0.022 & 0.99 & 7 & -0.003 & -0.74 & 0.036 & $2.85 * * *$ \\
\hline-23 & 0.001 & 0.13 & 0.022 & 1.04 & 8 & 0.000 & 0.09 & 0.036 & $2.72 * * *$ \\
\hline-22 & 0.006 & 1.43 & 0.029 & 1.36 & 9 & -0.004 & -0.85 & 0.032 & $2.31 * *$ \\
\hline-21 & 0.002 & 0.51 & 0.031 & 1.50 & 10 & -0.006 & -1.29 & 0.027 & 1.81 \\
\hline-20 & 0.003 & 0.57 & 0.034 & 1.65 & 11 & -0.009 & -1.93 & 0.018 & 1.18 \\
\hline-19 & 0.002 & 0.45 & 0.036 & 1.80 & 12 & 0.000 & 0.10 & 0.019 & 1.16 \\
\hline-18 & -0.002 & -0.49 & 0.033 & 1.73 & 13 & 0.001 & 0.27 & 0.020 & 1.19 \\
\hline-17 & 0.004 & 1.01 & 0.038 & $2.02 * *$ & 14 & -0.012 & $-2.69 * *$ & 0.008 & 0.45 \\
\hline-16 & 0.004 & 0.92 & 0.042 & $2.30 * *$ & 15 & 0.000 & 0.01 & 0.008 & 0.44 \\
\hline-15 & -0.006 & -1.32 & 0.036 & $2.04 * *$ & 16 & -0.018 & $-4.06 * *$ & -0.010 & -0.56 \\
\hline-14 & 0.002 & 0.50 & 0.038 & $2.23 * *$ & 17 & -0.004 & -0.99 & -0.015 & -0.77 \\
\hline-13 & -0.001 & -0.14 & 0.038 & $2.28 * *$ & 18 & -0.005 & -1.15 & -0.020 & -1.02 \\
\hline-12 & -0.001 & -0.34 & 0.036 & $2.27 * *$ & 19 & 0.000 & 0.02 & -0.020 & -0.99 \\
\hline-11 & 0.001 & 0.31 & 0.038 & $2.45 * *$ & 20 & 0.005 & 1.04 & -0.015 & -0.73 \\
\hline-10 & 0.001 & 0.23 & 0.039 & $2.63 * * *$ & 21 & -0.002 & -0.37 & -0.017 & -0.80 \\
\hline-9 & 0.000 & 0.11 & 0.039 & $2.79 * * *$ & 22 & -0.003 & -0.67 & -0.020 & -0.92 \\
\hline-8 & -0.001 & -0.27 & 0.038 & $2.85 * * *$ & 23 & 0.001 & 0.29 & -0.018 & -0.84 \\
\hline-7 & -0.006 & -1.42 & 0.032 & $2.52 * *$ & 24 & -0.003 & -0.59 & -0.021 & -0.94 \\
\hline-6 & 0.001 & 0.18 & 0.032 & $2.76 * * *$ & 25 & 0.003 & 0.78 & -0.017 & -0.77 \\
\hline-5 & 0.002 & 0.46 & 0.034 & $3.17 * * *$ & 26 & -0.003 & -0.64 & -0.020 & -0.88 \\
\hline-4 & -0.008 & -1.84 & 0.026 & $2.65 * * *$ & 27 & -0.004 & -0.98 & -0.025 & -1.05 \\
\hline-3 & -0.003 & -0.62 & 0.024 & $2.65 * * *$ & 28 & 0.002 & 0.38 & -0.023 & -0.96 \\
\hline-2 & -0.007 & -1.60 & 0.016 & $2.14 * *$ & 29 & -0.002 & -0.37 & -0.025 & -1.01 \\
\hline-1 & -0.001 & -0.16 & 0.016 & $2.51 * *$ & 30 & 0.001 & 0.32 & -0.023 & -0.94 \\
\hline 0 & -0.003 & -0.63 & 0.013 & $2.92 * * *$ & & & & & \\
\hline
\end{tabular}

*** indicates significant at 1 percent level. $* *$ indicates significant at 5 percent level.

In figure 1 CAARs and AARs for the entire sample is presented. In the figure CAAR shows an "M shape" where CAAR increases before and after the announcement of bonus issue in the DSE. However, no specific pattern is observed in AARs. 


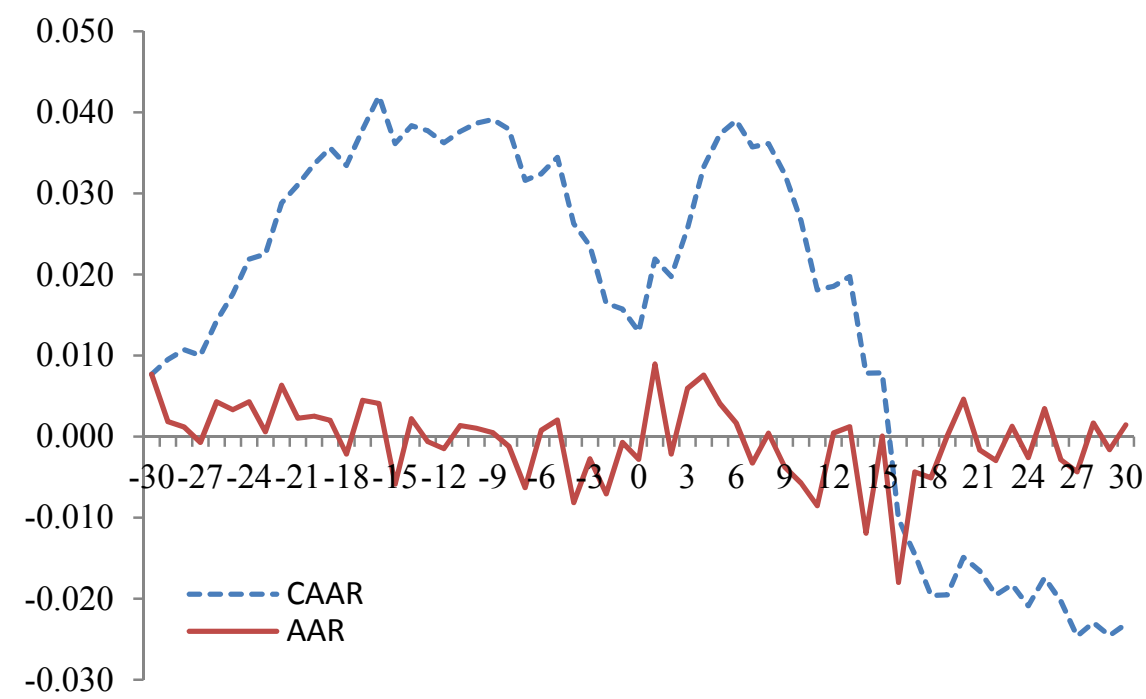

Figure 1. AAR \& CAAR (T-30 to $\mathrm{T}+30)$ for the entire sample

Table 5 exhibits empirical results of the Engineering sector which consists of twenty nine samples that announced bonus share during the sample period. No consistent pattern in AAR or in CAAR is observed before and after the announcement date. The significant positive response in AAR in preannouncement period shows that the news of bonus issues has been leaked out prior to the announcement of bonus issues. All the CAAR in the pre-announcement period is positive while it becomes negative starting from $t+21$. The AARs before the announcement period ( -30 to -1 day) are negative for 17 days out of 30 days and are positive only for 13 days. For observations before the announcement date, no significant abnormal return is observed. The AARs after the announcement date show no consistent pattern. After the announcement date for 17 days there were positive returns and for rest of the days there were negative returns. AARs are significant at $5 \%$ level only on day $t=0$ and on $t+16$.

The analysis of CAAR in table 5 also shows that in the pre-event window CAAR became negative on $t-7$ and continues to be negative till $t+7$. CAARs start to pick up on day $t+2$, and become positive on $t+12$ which is $0.30 \%$. However, CAARs on the announcement day is $-3 \%$ and decreases to $-3.4 \%$ on $t+1$ which defies traditional theories that market reacts positively to the announcement of a bonus issue and thus supports Papaioannou, Travlos, and Tsangarakis (2000) results. The absence of significant abnormal returns occurring before and after the announcement date implies that the investors have failed to anticipate the informational content of the event, or that they did not have access to inside information.

Table 5. Daily AARs, CAARs, \& respective t-test statistics of engineering sector

\begin{tabular}{|c|c|c|c|c|c|c|c|c|c|}
\hline $\mathbf{T}$ & $\mathbf{A A R}$ & $\begin{array}{l}t \text {-test } \\
\text { (AAR) }\end{array}$ & CAAR & $\begin{array}{l}t \text {-test } \\
\text { (CAAR) }\end{array}$ & $\mathbf{T}$ & AAR & $\begin{array}{l}t \text {-test } \\
(\mathrm{AAR})\end{array}$ & CAAR & $\begin{array}{l}t \text {-test } \\
\text { (CAAR) }\end{array}$ \\
\hline-30 & -0.005 & -0.366 & -0.005 & -0.066 & 1 & -0.004 & -0.310 & -0.034 & -1.855 \\
\hline-29 & 0.002 & 0.148 & -0.003 & -0.040 & 2 & 0.009 & 0.667 & -0.026 & -1.130 \\
\hline-28 & 0.001 & 0.075 & -0.002 & -0.027 & 3 & 0.007 & 0.546 & -0.018 & -0.705 \\
\hline-27 & 0.001 & 0.106 & 0.000 & -0.007 & 4 & 0.011 & 0.858 & -0.007 & -0.247 \\
\hline-26 & -0.001 & -0.066 & -0.001 & -0.020 & 5 & 0.007 & 0.534 & 0.000 & -0.008 \\
\hline-25 & 0.005 & 0.389 & 0.004 & 0.056 & 6 & -0.007 & -0.557 & -0.008 & -0.218 \\
\hline-24 & 0.007 & 0.545 & 0.011 & 0.166 & 7 & 0.002 & 0.130 & -0.006 & -0.158 \\
\hline-23 & -0.004 & -0.313 & 0.007 & 0.105 & 8 & 0.002 & 0.176 & -0.004 & -0.090 \\
\hline-22 & 0.008 & 0.617 & 0.015 & 0.236 & 9 & 0.002 & 0.188 & -0.001 & -0.026 \\
\hline-21 & 0.001 & 0.107 & 0.016 & 0.264 & 10 & -0.001 & -0.062 & -0.002 & -0.044 \\
\hline-20 & 0.002 & 0.131 & 0.018 & 0.299 & 11 & -0.004 & -0.269 & -0.005 & -0.119 \\
\hline-19 & -0.002 & -0.166 & 0.016 & 0.269 & 12 & 0.008 & 0.640 & 0.003 & 0.063 \\
\hline-18 & -0.007 & -0.553 & 0.009 & 0.150 & 13 & 0.000 & 0.018 & 0.003 & 0.065 \\
\hline-17 & 0.010 & 0.796 & 0.019 & 0.341 & 14 & -0.010 & -0.744 & -0.007 & -0.129 \\
\hline-16 & 0.005 & 0.365 & 0.024 & 0.440 & 15 & -0.001 & -0.086 & -0.008 & -0.146 \\
\hline-15 & -0.003 & -0.221 & 0.021 & 0.398 & 16 & -0.043 & $-3.27 * * *$ & -0.050 & -0.936 \\
\hline-14 & 0.008 & 0.648 & 0.029 & 0.579 & 17 & -0.010 & -0.762 & -0.060 & -1.089 \\
\hline
\end{tabular}




\begin{tabular}{|c|c|c|c|c|c|c|c|c|c|}
\hline-13 & -0.003 & -0.216 & 0.026 & 0.541 & 18 & 0.003 & 0.199 & -0.058 & -1.014 \\
\hline-12 & -0.006 & -0.458 & 0.020 & 0.435 & 19 & -0.011 & -0.851 & -0.069 & -1.179 \\
\hline-11 & 0.002 & 0.145 & 0.022 & 0.494 & 20 & 0.010 & 0.768 & -0.059 & -0.983 \\
\hline-10 & -0.003 & -0.215 & 0.020 & 0.452 & 21 & -0.003 & -0.221 & -0.062 & -1.007 \\
\hline-9 & -0.005 & -0.411 & 0.014 & 0.344 & 22 & 0.001 & 0.039 & -0.061 & -0.977 \\
\hline-8 & -0.009 & -0.712 & 0.005 & 0.125 & 23 & 0.012 & 0.948 & -0.049 & -0.763 \\
\hline-7 & -0.009 & -0.720 & -0.005 & -0.122 & 24 & -0.008 & -0.644 & -0.057 & -0.876 \\
\hline-6 & -0.005 & -0.374 & -0.009 & -0.272 & 25 & 0.008 & 0.627 & -0.049 & -0.737 \\
\hline-5 & -0.002 & -0.129 & -0.011 & -0.346 & 26 & -0.003 & -0.236 & -0.052 & -0.768 \\
\hline-4 & -0.001 & -0.083 & -0.012 & -0.417 & 27 & 0.004 & 0.321 & -0.048 & -0.694 \\
\hline-3 & -0.004 & -0.313 & -0.016 & -0.623 & 28 & 0.011 & 0.874 & -0.036 & -0.519 \\
\hline-2 & -0.003 & -0.263 & -0.020 & -0.870 & 29 & -0.006 & -0.460 & -0.042 & -0.595 \\
\hline-1 & 0.003 & 0.265 & -0.016 & -0.879 & 30 & 0.003 & 0.245 & -0.039 & -0.541 \\
\hline 0 & -0.014 & -1.071 & -0.030 & $-2.314 * *$ & & & & & \\
\hline
\end{tabular}

$* * *$ indicates significant at 1 percent level. $* *$ indicates significant at 5 percent level.

Table 6 presents results of the Cement sector which contains sixteen samples which announced bonus share during the sample period. No consistent significant pattern in AAR is observed before and after the announcement of bonus issue. The AARs before the announcement period are positive for 15 days out of 30 days. For observations before and after the announcement date, no significant abnormal return is observed. In post-announcement period, AARs for 12 days are negative. CAARs in the pre-announcement period are turn out to be negative in $t-16$ and continues to be negative even in the whole post-announcement period.

Table 6. Daily AARs, CAARs, \& respective t-test statistics of cement sector

\begin{tabular}{|c|c|c|c|c|c|c|c|c|c|}
\hline $\mathbf{T}$ & AAR & $\begin{array}{l}t \text {-test } \\
\text { (AAR) }\end{array}$ & CAAR & $\begin{array}{l}t \text {-test } \\
\text { (CAAR) }\end{array}$ & $\mathbf{T}$ & AAR & $\begin{array}{l}t \text {-test } \\
\text { (AAR) }\end{array}$ & CAAR & $\begin{array}{l}t \text {-test } \\
\text { (CAAR) }\end{array}$ \\
\hline-30 & 0.004 & 0.384 & 0.004 & 0.069 & 1 & 0.005 & 0.458 & -0.035 & $-2.257 * *$ \\
\hline-29 & 0.005 & 0.490 & 0.010 & 0.160 & 2 & 0.004 & 0.366 & -0.031 & -1.631 \\
\hline-28 & -0.002 & -0.186 & 0.008 & 0.128 & 3 & 0.000 & 0.035 & -0.031 & -1.395 \\
\hline-27 & -0.002 & -0.170 & 0.006 & 0.098 & 4 & 0.003 & 0.298 & -0.028 & -1.115 \\
\hline-26 & 0.018 & 1.624 & 0.024 & 0.412 & 5 & -0.012 & -1.124 & -0.040 & -1.476 \\
\hline-25 & 0.003 & 0.307 & 0.027 & 0.480 & 6 & -0.003 & -0.261 & -0.043 & -1.466 \\
\hline-24 & -0.002 & -0.168 & 0.025 & 0.456 & 7 & 0.011 & 1.018 & -0.032 & -1.011 \\
\hline-23 & -0.001 & -0.065 & 0.025 & 0.452 & 8 & 0.008 & 0.718 & -0.024 & -0.714 \\
\hline-22 & 0.008 & 0.745 & 0.033 & 0.617 & 9 & -0.034 & -3.046 & -0.058 & -1.640 \\
\hline-21 & 0.005 & 0.438 & 0.038 & 0.725 & 10 & 0.005 & 0.433 & -0.053 & -1.433 \\
\hline-20 & 0.005 & 0.438 & 0.043 & 0.837 & 11 & 0.006 & 0.511 & -0.047 & -1.225 \\
\hline-19 & 0.002 & 0.208 & 0.045 & 0.905 & 12 & -0.007 & -0.674 & -0.055 & -1.364 \\
\hline-18 & -0.008 & -0.743 & 0.037 & 0.758 & 13 & 0.004 & 0.334 & -0.051 & -1.225 \\
\hline-17 & 0.010 & 0.877 & 0.046 & 0.985 & 14 & 0.000 & -0.032 & -0.051 & -1.191 \\
\hline-16 & 0.012 & 1.060 & 0.058 & 1.271 & 15 & 0.019 & 1.682 & -0.033 & -0.733 \\
\hline-15 & -0.060 & $-5.42 * * *$ & -0.002 & -0.045 & 16 & 0.005 & 0.417 & -0.028 & -0.610 \\
\hline-14 & -0.001 & -0.064 & -0.003 & -0.063 & 17 & -0.004 & -0.341 & -0.032 & -0.673 \\
\hline-13 & -0.003 & -0.312 & -0.006 & -0.149 & 18 & -0.008 & -0.742 & -0.040 & -0.826 \\
\hline-12 & 0.001 & 0.122 & -0.005 & -0.120 & 19 & 0.004 & 0.379 & -0.036 & -0.720 \\
\hline-11 & -0.002 & -0.187 & -0.007 & -0.179 & 20 & 0.002 & 0.205 & -0.033 & -0.658 \\
\hline-10 & -0.002 & -0.185 & -0.009 & -0.243 & 21 & 0.015 & 1.338 & -0.019 & -0.358 \\
\hline-9 & -0.007 & -0.594 & -0.016 & -0.443 & 22 & 0.023 & 2.034 & 0.004 & 0.074 \\
\hline-8 & -0.007 & -0.608 & -0.022 & -0.670 & 23 & -0.026 & -2.336 & -0.022 & -0.404 \\
\hline-7 & 0.005 & 0.410 & -0.018 & -0.565 & 24 & -0.006 & -0.562 & -0.028 & -0.508 \\
\hline-6 & -0.001 & -0.093 & -0.019 & -0.640 & 25 & -0.005 & -0.494 & -0.034 & -0.595 \\
\hline-5 & 0.005 & 0.496 & -0.013 & -0.488 & 26 & -0.005 & -0.411 & -0.038 & -0.663 \\
\hline-4 & -0.002 & -0.223 & -0.016 & -0.635 & 27 & -0.002 & -0.224 & -0.041 & -0.694 \\
\hline-3 & -0.005 & -0.443 & -0.021 & -0.931 & 28 & -0.011 & -0.977 & -0.052 & -0.863 \\
\hline-2 & -0.012 & -1.049 & -0.032 & -1.681 & 29 & 0.001 & 0.078 & -0.051 & -0.834 \\
\hline-1 & 0.007 & 0.631 & -0.025 & -1.612 & 30 & 0.016 & 1.444 & -0.035 & -0.562 \\
\hline 0 & -0.015 & -1.369 & -0.040 & $-3.649 * * *$ & & & & & \\
\hline
\end{tabular}

*** indicates significant at 1 percent level. ** indicates significant at 5 percent level.

Table 7 presents the empirical results of the Food \& Allied Sector consisting of ten bonus issues. No constant pattern in AARs is observed. On the announcement day AAR is $4 \%$. In the pre-event window, including the announcement day, AAR is significant on $t-23$ and $t-12$. The AARs before the announcement period are positive for 22 days out of 30 days and are negative for 8 days. AARs in the post-announcement period are positive for 17 days out of 30 days. The analysis of CAAR in table 7, shows strong statistical constant patter has been found, i.e., CAAR is positive and statistically significant on day $t-12$ to $t+10$. However, on day $t+14$, CAAR becomes 
negative. The presence of significant abnormal returns before and after the announcement date implies that the investors have anticipated the informational content of the event, or that they have accessed to inside information.

Table 7. Daily AARs, CAARs, \& respective t-test statistics of food $\&$ allied sector

\begin{tabular}{|c|c|c|c|c|c|c|c|c|c|}
\hline $\mathbf{T}$ & AAR & $\begin{array}{l}t \text {-test } \\
\text { (AAR) }\end{array}$ & CAAR & $\begin{array}{l}t \text {-test } \\
\text { (CAAR) }\end{array}$ & $\mathbf{T}$ & AAR & $\begin{array}{l}t \text {-test } \\
\text { (AAR) }\end{array}$ & CAAR & $\begin{array}{l}t \text {-test } \\
\text { (CAAR) }\end{array}$ \\
\hline-30 & 0.01 & 0.57 & 0.01 & 0.10 & 1 & 0.00 & -0.25 & 0.10 & $7.73 * * *$ \\
\hline-29 & 0.02 & 1.81 & 0.02 & 0.43 & 2 & -0.01 & -0.80 & 0.09 & $5.84 * * *$ \\
\hline-28 & -0.01 & -0.73 & 0.02 & 0.31 & 3 & 0.01 & 0.96 & 0.10 & $5.54 * * *$ \\
\hline-27 & 0.00 & 0.19 & 0.02 & 0.35 & 4 & 0.02 & 2.08 & 0.12 & $5.88 * * *$ \\
\hline-26 & -0.01 & -0.91 & 0.01 & 0.18 & 5 & -0.01 & -0.67 & 0.12 & $5.10 * * *$ \\
\hline-25 & 0.01 & 1.09 & 0.02 & 0.40 & 6 & 0.00 & -0.06 & 0.12 & $4.70 * * *$ \\
\hline-24 & 0.00 & 0.12 & 0.02 & 0.43 & 7 & -0.02 & -2.51 & 0.09 & $3.51 * * *$ \\
\hline-23 & 0.02 & $2.11 * *$ & 0.04 & 0.87 & 8 & -0.02 & -1.92 & 0.07 & $2.67 * * *$ \\
\hline-22 & 0.01 & 1.12 & 0.05 & 1.12 & 9 & -0.01 & -0.70 & 0.07 & $2.31 * *$ \\
\hline-21 & 0.01 & 1.46 & 0.06 & 1.46 & 10 & 0.00 & 0.01 & 0.07 & $2.20 * *$ \\
\hline-20 & 0.00 & -0.45 & 0.06 & 1.39 & 11 & -0.03 & -2.74 & 0.04 & 1.32 \\
\hline-19 & -0.01 & -1.22 & 0.05 & 1.15 & 12 & 0.03 & 3.06 & 0.07 & $2.11 * *$ \\
\hline-18 & 0.00 & -0.43 & 0.04 & 1.08 & 13 & 0.01 & 0.81 & 0.08 & $2.25 * *$ \\
\hline-17 & 0.00 & 0.14 & 0.05 & 1.15 & 14 & -0.09 & -9.23 & -0.01 & -0.21 \\
\hline-16 & 0.01 & 1.13 & 0.06 & 1.46 & 15 & -0.02 & -2.35 & -0.03 & -0.79 \\
\hline-15 & -0.01 & -0.59 & 0.05 & 1.35 & 16 & 0.03 & 3.65 & 0.00 & 0.12 \\
\hline-14 & 0.01 & 1.15 & 0.06 & 1.69 & 17 & 0.00 & -0.49 & 0.00 & 0.00 \\
\hline-13 & -0.02 & -1.73 & 0.05 & 1.29 & 18 & 0.00 & -0.37 & 0.00 & -0.08 \\
\hline-12 & 0.02 & $2.56 * *$ & 0.07 & $2.05 * *$ & 19 & 0.01 & 0.81 & 0.00 & 0.10 \\
\hline-11 & 0.01 & 1.43 & 0.08 & $2.55 * *$ & 20 & 0.00 & -0.27 & 0.00 & 0.04 \\
\hline-10 & -0.01 & -0.97 & 0.07 & $2.37 * *$ & 21 & 0.02 & 2.00 & 0.02 & 0.47 \\
\hline-9 & 0.01 & 1.20 & 0.08 & $2.86 * * *$ & 22 & -0.01 & -1.20 & 0.01 & 0.21 \\
\hline-8 & 0.00 & -0.26 & 0.08 & $2.93 * * *$ & 23 & 0.01 & 1.44 & 0.02 & 0.50 \\
\hline-7 & 0.00 & -0.33 & 0.08 & $2.99 * * *$ & 24 & 0.03 & 2.74 & 0.05 & 1.03 \\
\hline-6 & 0.00 & 0.18 & 0.08 & $3.27 * * *$ & 25 & -0.01 & -1.22 & 0.04 & 0.78 \\
\hline-5 & 0.00 & 0.09 & 0.08 & $3.57 * * *$ & 26 & -0.01 & -1.03 & 0.03 & 0.56 \\
\hline-4 & -0.01 & -1.12 & 0.07 & $3.40 * * *$ & 27 & -0.02 & -1.62 & 0.01 & 0.25 \\
\hline-3 & 0.00 & -0.06 & 0.07 & $3.77 * * *$ & 28 & 0.00 & 0.20 & 0.01 & 0.28 \\
\hline-2 & 0.00 & 0.45 & 0.07 & $4.61 * * *$ & 29 & -0.01 & -1.01 & 0.00 & 0.09 \\
\hline-1 & -0.01 & -0.70 & 0.07 & $5.15 * * *$ & 30 & 0.01 & 0.61 & 0.01 & 0.20 \\
\hline 0 & 0.04 & $3.89 * * *$ & 0.10 & $11.18^{* * *}$ & & & & & \\
\hline
\end{tabular}

Table 8 shows results of the Fuel \& Power Sector consisting of 20 bonus issues. No consistent pattern in AARs is observed. The AARs before the announcement period ( -30 to -1 day) are positive only for 16 days out of 30 days. For observations before the announcement date, on day $t-7, t-4$ and $t-2$ significant abnormal return is observed. The AARs after the announcement date also show no consistent pattern. After the announcement date for 12 days there were positive returns. After the announcement date, AARs are significant on day $t+10, t+16$, $t+21$ and on $t+28$.

The analysis of CAAR in table 8 shows that during pre-event window CAAR becomes negative on $t-4$ and continues to be negative for the whole post announcement period, i.e., $t+30$. A consistent pattern in CAAR is observed: from day $t-2$ to $t+5$, i.e., for 8 days, and from day $t+10$ to $t+30$, i.e., for 21 days, statistically significant CAAR has been detected. The presence of significant abnormal returns before and after the announcement date could be interpreted as investors have anticipated the informational content of the event, or that they have accessed to inside information in DSE.

Table 8. Daily AARs, CAARs, \& respective t-test statistics of fuel \& power sector

\begin{tabular}{|c|c|c|c|c|c|c|c|c|c|}
\hline $\mathbf{T}$ & AAR & $\begin{array}{l}t \text {-test } \\
\text { (AAR) }\end{array}$ & CAAR & $\begin{array}{l}t \text {-test } \\
\text { (CAAR) }\end{array}$ & $\mathbf{T}$ & AAR & $\begin{array}{l}t \text {-test } \\
\text { (AAR) }\end{array}$ & CAAR & $\begin{array}{l}t \text {-test } \\
\text { (CAAR) }\end{array}$ \\
\hline-30 & 0.002 & 0.21 & 0.002 & 0.04 & 1 & 0.008 & 0.94 & -0.051 & $-4.28 * * *$ \\
\hline-29 & 0.003 & 0.40 & 0.005 & 0.11 & 2 & 0.009 & 1.09 & -0.042 & $-2.86 * * *$ \\
\hline-28 & -0.001 & -0.12 & 0.004 & 0.09 & 3 & -0.005 & -0.58 & -0.047 & $-2.77 * * *$ \\
\hline-27 & -0.001 & -0.08 & 0.003 & 0.08 & 4 & 0.004 & 0.49 & -0.042 & $-2.25 * *$ \\
\hline-26 & -0.009 & -1.11 & -0.006 & -0.13 & 5 & 0.002 & 0.23 & -0.040 & $-1.96 * *$ \\
\hline-25 & -0.009 & -1.05 & -0.015 & -0.34 & 6 & 0.007 & 0.83 & -0.033 & -1.51 \\
\hline-24 & 0.006 & 0.77 & -0.008 & -0.20 & 7 & -0.005 & -0.57 & -0.038 & -1.61 \\
\hline
\end{tabular}




\begin{tabular}{|c|c|c|c|c|c|c|c|c|c|}
\hline-23 & 0.003 & 0.32 & -0.006 & -0.14 & 8 & 0.003 & 0.39 & -0.035 & -1.39 \\
\hline-22 & 0.016 & 1.88 & 0.010 & 0.25 & 9 & -0.002 & -0.25 & -0.037 & -1.39 \\
\hline-21 & 0.018 & 2.12 & 0.028 & 0.71 & 10 & -0.025 & $-2.92 * * *$ & -0.062 & $-2.21 * *$ \\
\hline-20 & 0.011 & 1.32 & 0.039 & 1.02 & 11 & -0.005 & -0.55 & -0.066 & $-2.27 * *$ \\
\hline-19 & 0.011 & 1.27 & 0.050 & 1.33 & 12 & -0.008 & -0.95 & -0.074 & $-2.45 * *$ \\
\hline-18 & -0.009 & -1.06 & 0.041 & 1.12 & 13 & -0.002 & -0.23 & -0.076 & $-2.42 * *$ \\
\hline-17 & -0.007 & -0.81 & 0.034 & 0.96 & 14 & 0.005 & 0.56 & -0.072 & $-2.20 * *$ \\
\hline-16 & -0.008 & -0.92 & 0.026 & 0.76 & 15 & -0.002 & -0.20 & -0.073 & $-2.18 * *$ \\
\hline-15 & 0.007 & 0.78 & 0.033 & 0.98 & 16 & -0.021 & $-2.49 * *$ & -0.094 & $-2.72 * * *$ \\
\hline-14 & 0.005 & 0.55 & 0.038 & 1.15 & 17 & -0.001 & -0.17 & -0.096 & $-2.68 * * *$ \\
\hline-13 & -0.001 & -0.06 & 0.037 & 1.18 & 18 & -0.014 & -1.72 & -0.110 & $-3.00 * * *$ \\
\hline-12 & 0.002 & 0.21 & 0.039 & 1.28 & 19 & -0.001 & -0.06 & -0.111 & $-2.94 * * *$ \\
\hline-11 & 0.003 & 0.36 & 0.042 & 1.44 & 20 & 0.007 & 0.84 & -0.103 & $-2.68 * * *$ \\
\hline-10 & 0.004 & 0.42 & 0.045 & 1.63 & 21 & -0.018 & $-2.15 * *$ & -0.122 & $-3.08 * * *$ \\
\hline-9 & 0.008 & 0.93 & 0.053 & $2.00 * *$ & 22 & -0.008 & -0.99 & -0.130 & $-3.22 * * *$ \\
\hline-8 & 0.007 & 0.86 & 0.061 & $2.40 * *$ & 23 & 0.008 & 0.97 & -0.122 & $-2.95 * * *$ \\
\hline-7 & -0.025 & $-3.00 * * *$ & 0.035 & 1.49 & 24 & -0.005 & -0.54 & -0.126 & $-3.00 * * *$ \\
\hline-6 & 0.007 & 0.83 & 0.042 & 1.90 & 25 & 0.013 & 1.51 & -0.114 & $-2.65 * * *$ \\
\hline-5 & 0.002 & 0.19 & 0.044 & $2.13 * *$ & 26 & 0.011 & 1.29 & -0.103 & $-2.35 * *$ \\
\hline-4 & -0.050 & $-5.99 * * *$ & -0.006 & -0.34 & 27 & -0.008 & -0.97 & -0.111 & $-2.49 * *$ \\
\hline-3 & -0.006 & -0.68 & -0.012 & -0.72 & 28 & 0.022 & $2.65 * * *$ & -0.089 & $-1.96 * *$ \\
\hline-2 & -0.019 & $-2.25 * *$ & -0.031 & $-2.13 * *$ & 29 & -0.007 & -0.81 & -0.095 & $-2.07 * *$ \\
\hline-1 & -0.015 & -1.81 & -0.046 & $-3.89 * * *$ & 30 & -0.005 & -0.54 & -0.100 & $-2.13 * *$ \\
\hline 0 & -0.013 & -1.49 & -0.059 & $-6.99 * * *$ & & & & & \\
\hline
\end{tabular}

*** indicates significant at 1 percent level. ** indicates significant at 5 percent level.

Table 9 shows the empirical results of the Pharmaceuticals \& Chemicals Sector of DSE. During the sample period thirty firms in the Pharmaceuticals \& Chemicals sector declared stock dividend. No consistent pattern in AAR is found before and after the announcement date of bonus issue. The AARs before the announcement period are positive for 18 days out of 30 days. After the announcement date, out of 30 days 15 days had positive AARs. Both before and after the announcement of bonus issues, all the CAARs are positive. From the day $t-19$ to $t+23$, a statistically significant consistent pattern is observed in CAAR. For the Pharmaceuticals \& Chemicals sector it has been observed that CAARs start to pick up on day $t+1$, and increases to $14.17 \%$ on day $t+7$. On announcement day there was an increase in CAAR from 6.65 percent to 7.64 percent. The presence of significant and a consistent pattern in CAAR occurring before and after the announcement date implies that the investors have anticipated the informational content of the event, or that they have gained access to inside information.

Table 9. Daily AARs, CAARs, \& respective t-test statistics of pharmaceuticals \& chemicals sector

\begin{tabular}{|c|c|c|c|c|c|c|c|c|c|}
\hline $\mathbf{T}$ & AAR & $\begin{array}{l}t \text {-test } \\
\text { (AAR) }\end{array}$ & CAAR & $\begin{array}{l}t \text {-test } \\
\text { (CAAR) }\end{array}$ & $\mathbf{T}$ & AAR & $\begin{array}{l}t \text {-test } \\
\text { (AAR) }\end{array}$ & CAAR & $\begin{array}{l}t \text {-test } \\
\text { (CAAR) }\end{array}$ \\
\hline-30 & 0.022 & $3.65 * * *$ & 0.022 & 0.66 & 1 & 0.057 & $9.44 * * *$ & 0.133 & $15.71 * * *$ \\
\hline-29 & -0.004 & -0.69 & 0.018 & 0.54 & 2 & -0.022 & $-3.61 * * *$ & 0.111 & $10.74 * * *$ \\
\hline-28 & 0.002 & 0.28 & 0.019 & 0.60 & 3 & 0.003 & 0.52 & 0.114 & $9.56 * * *$ \\
\hline-27 & 0.001 & 0.20 & 0.021 & 0.65 & 4 & -0.002 & -0.36 & 0.112 & $8.39 * * *$ \\
\hline-26 & 0.011 & 1.80 & 0.031 & 1.01 & 5 & 0.013 & $2.23 * *$ & 0.126 & $8.57 * * *$ \\
\hline-25 & 0.012 & $1.96 * *$ & 0.043 & 1.41 & 6 & 0.013 & $2.18 * *$ & 0.139 & $8.75 * * *$ \\
\hline-24 & 0.000 & 0.02 & 0.043 & 1.45 & 7 & -0.005 & -0.79 & 0.134 & $7.91 * * *$ \\
\hline-23 & -0.001 & -0.25 & 0.042 & 1.42 & 8 & 0.000 & 0.08 & 0.134 & $7.48 * * *$ \\
\hline-22 & 0.002 & 0.25 & 0.043 & 1.51 & 9 & 0.007 & 1.22 & 0.142 & $7.49 * * *$ \\
\hline-21 & -0.002 & -0.29 & 0.042 & 1.48 & 10 & 0.000 & -0.01 & 0.142 & $7.13 * * *$ \\
\hline-20 & 0.003 & 0.44 & 0.044 & 1.61 & 11 & -0.007 & -1.11 & 0.135 & $6.51 * * *$ \\
\hline-19 & 0.014 & $2.34 * *$ & 0.058 & $2.17 * *$ & 12 & -0.024 & $-4.09 * * *$ & 0.111 & $5.12 * * *$ \\
\hline-18 & 0.001 & 0.16 & 0.059 & $2.27 * *$ & 13 & -0.011 & -1.91 & 0.099 & $4.42 * * *$ \\
\hline-17 & 0.000 & 0.00 & 0.059 & $2.33 * *$ & 14 & -0.021 & $-3.45 * * *$ & 0.078 & $3.39 * * *$ \\
\hline-16 & 0.011 & 1.83 & 0.070 & $2.84 * * *$ & 15 & 0.000 & -0.01 & 0.078 & $3.28 * * *$ \\
\hline-15 & 0.004 & 0.60 & 0.074 & $3.08 * * *$ & 16 & -0.010 & -1.63 & 0.069 & $2.78 * * *$ \\
\hline-14 & -0.003 & -0.56 & 0.070 & $3.03 * * *$ & 17 & -0.005 & -0.78 & 0.064 & $2.52 * *$ \\
\hline-13 & 0.002 & 0.38 & 0.073 & $3.24 * * *$ & 18 & -0.002 & -0.26 & 0.062 & $2.39 * *$ \\
\hline-12 & -0.006 & -0.93 & 0.067 & $3.11 * * *$ & 19 & 0.011 & 1.76 & 0.073 & $2.73 * * *$ \\
\hline-11 & 0.000 & -0.01 & 0.067 & $3.23 * * *$ & 20 & 0.006 & 0.99 & 0.079 & $2.88 * * *$ \\
\hline-10 & 0.010 & 1.64 & 0.077 & $3.87 * * *$ & 21 & -0.004 & -0.65 & 0.075 & $2.67 * * *$ \\
\hline-9 & -0.001 & -0.24 & 0.075 & $3.98 * * *$ & 22 & -0.014 & $-2.34 * *$ & 0.061 & $2.12 * *$ \\
\hline-8 & -0.002 & -0.32 & 0.073 & $4.09 * * *$ & 23 & 0.000 & 0.04 & 0.061 & $2.09 * *$ \\
\hline-7 & -0.004 & -0.69 & 0.069 & $4.09 * * *$ & 24 & -0.007 & -1.16 & 0.054 & 1.81 \\
\hline-6 & 0.003 & 0.46 & 0.072 & $4.55 * * *$ & 25 & 0.009 & 1.46 & 0.063 & $2.06 * *$ \\
\hline-5 & -0.001 & -0.14 & 0.071 & $4.86 * * *$ & 26 & -0.009 & -1.50 & 0.054 & 1.74 \\
\hline-4 & -0.003 & -0.55 & 0.068 & $5.08 * * *$ & 27 & 0.000 & -0.08 & 0.054 & 1.69 \\
\hline
\end{tabular}




\begin{tabular}{ccllllllll}
-3 & -0.001 & -0.21 & 0.067 & $5.57 * * *$ & 28 & 0.000 & 0.00 & 0.054 & 1.66 \\
-2 & -0.005 & -0.76 & 0.062 & $5.99 * * *$ & 29 & 0.004 & 0.62 & 0.057 & 1.75 \\
-1 & 0.004 & 0.73 & 0.067 & $7.86 * * *$ & 30 & -0.003 & -0.46 & 0.055 & 1.64 \\
0 & 0.010 & 1.65 & 0.076 & $12.77 * * *$ & & & & & \\
\hline
\end{tabular}

*** indicates significant at 1 percent level. $* *$ indicates significant at 5 percent level.

Table 10 presents results for the Textile sector which consists of thirty one samples. Even though no consistent pattern in CAAR is observed before and after the announcement date, from day $t-4$ to $t=0$ a statistically significant consistent pattern is observed in AAR. The significant positive response in AAR in pre-announcement period shows that the news of right issues has been leaked out prior to the announcement of bonus issues. All the CAAR in the pre-announcement period is positive while it becomes negative starting from $t+21$. On $t$-2, CAAR stats to decline substantially and continues to do so till day $t+2$ and then starts to increase again which defies traditional theories that market reacts positively to the announcement of a bonus issue and thus supports Malhotra, Thenmozhi and Gopalaswamy (2012), Papaioannou, Travlos, and Tsangarakis (2000), and Dhatt, Kim and Mukherji (1997) results.

Table 10. Daily AARs, CAARs, \& respective t-test statistics of textile sector

\begin{tabular}{|c|c|c|c|c|c|c|c|c|c|}
\hline $\mathbf{T}$ & AAR & $\begin{array}{l}t \text {-test } \\
\text { (AAR) }\end{array}$ & CAAR & $\begin{array}{l}\text {-test } \\
\text { (CAAR) }\end{array}$ & $\mathbf{T}$ & AAR & $\begin{array}{l}t \text {-test } \\
\text { (AAR) }\end{array}$ & CAAR & $\begin{array}{l}t \text {-test } \\
\text { (CAAR) }\end{array}$ \\
\hline-30 & 0.01 & 1.08 & 0.01 & 0.19 & 1 & -0.02 & -1.69 & 0.02 & 1.12 \\
\hline-29 & 0.00 & -0.02 & 0.01 & 0.19 & 2 & 0.00 & -0.21 & 0.02 & 0.80 \\
\hline-28 & 0.01 & 0.60 & 0.02 & 0.31 & 3 & 0.02 & 1.49 & 0.03 & 1.44 \\
\hline-27 & 0.00 & -0.43 & 0.01 & 0.23 & 4 & 0.01 & 1.29 & 0.05 & 1.86 \\
\hline-26 & 0.01 & 0.79 & 0.02 & 0.39 & 5 & 0.01 & 0.50 & 0.05 & 1.90 \\
\hline-25 & 0.00 & -0.08 & 0.02 & 0.38 & 6 & 0.00 & -0.11 & 0.05 & 1.72 \\
\hline-24 & 0.01 & 0.77 & 0.03 & 0.54 & 7 & -0.01 & -0.59 & 0.04 & 1.40 \\
\hline-23 & 0.00 & 0.01 & 0.03 & 0.56 & 8 & 0.00 & -0.11 & 0.04 & 1.28 \\
\hline-22 & 0.00 & 0.08 & 0.03 & 0.59 & 9 & 0.00 & -0.45 & 0.04 & 1.07 \\
\hline-21 & -0.01 & -0.73 & 0.02 & 0.44 & 10 & -0.01 & -1.00 & 0.03 & 0.72 \\
\hline-20 & 0.00 & -0.12 & 0.02 & 0.43 & 11 & -0.02 & -1.76 & 0.01 & 0.18 \\
\hline-19 & -0.01 & -0.65 & 0.01 & 0.29 & 12 & 0.02 & 1.60 & 0.02 & 0.62 \\
\hline-18 & 0.01 & 0.69 & 0.02 & 0.46 & 13 & 0.01 & 1.17 & 0.04 & 0.91 \\
\hline-17 & 0.01 & 0.81 & 0.03 & 0.66 & 14 & 0.00 & 0.16 & 0.04 & 0.92 \\
\hline-16 & 0.00 & -0.15 & 0.03 & 0.64 & 15 & 0.00 & -0.01 & 0.04 & 0.89 \\
\hline-15 & 0.00 & 0.19 & 0.03 & 0.71 & 16 & -0.03 & -2.67 & 0.01 & 0.21 \\
\hline-14 & 0.00 & -0.09 & 0.03 & 0.71 & 17 & 0.00 & -0.10 & 0.01 & 0.19 \\
\hline-13 & 0.01 & 0.46 & 0.04 & 0.86 & 18 & -0.01 & -0.77 & 0.00 & 0.00 \\
\hline-12 & -0.01 & -0.46 & 0.03 & 0.76 & 19 & 0.00 & -0.34 & 0.00 & -0.07 \\
\hline-11 & 0.00 & -0.09 & 0.03 & 0.77 & 20 & 0.00 & 0.02 & 0.00 & -0.07 \\
\hline-10 & 0.00 & -0.06 & 0.03 & 0.78 & 21 & 0.00 & -0.26 & -0.01 & -0.12 \\
\hline-9 & 0.00 & 0.29 & 0.03 & 0.91 & 22 & 0.00 & -0.23 & -0.01 & -0.17 \\
\hline-8 & 0.00 & 0.44 & 0.04 & 1.11 & 23 & 0.00 & -0.23 & -0.01 & -0.21 \\
\hline-7 & 0.00 & 0.01 & 0.04 & 1.17 & 24 & 0.00 & 0.09 & -0.01 & -0.19 \\
\hline-6 & 0.00 & 0.07 & 0.04 & 1.28 & 25 & 0.00 & -0.24 & -0.01 & -0.23 \\
\hline-5 & 0.01 & 0.65 & 0.04 & 1.65 & 26 & 0.00 & -0.22 & -0.02 & -0.27 \\
\hline-4 & 0.01 & 0.51 & 0.05 & $2.03 * *$ & 27 & -0.01 & -1.01 & -0.03 & -0.45 \\
\hline-3 & 0.00 & -0.05 & 0.05 & $2.25 * *$ & 28 & -0.01 & -1.15 & -0.04 & -0.66 \\
\hline-2 & -0.01 & -0.60 & 0.04 & $2.25 * *$ & 29 & 0.00 & 0.18 & -0.04 & -0.62 \\
\hline-1 & 0.00 & -0.20 & 0.04 & $2.61 * * *$ & 30 & 0.00 & -0.11 & -0.04 & -0.63 \\
\hline 0 & 0.00 & -0.42 & 0.04 & $3.27 * * *$ & & & & & \\
\hline
\end{tabular}

\footnotetext{
*** indicates significant at 1 percent level. ** indicates significant at 5 percent level.
}

Sectoral Decomposition of CAARs is given in figure 2 in below: 


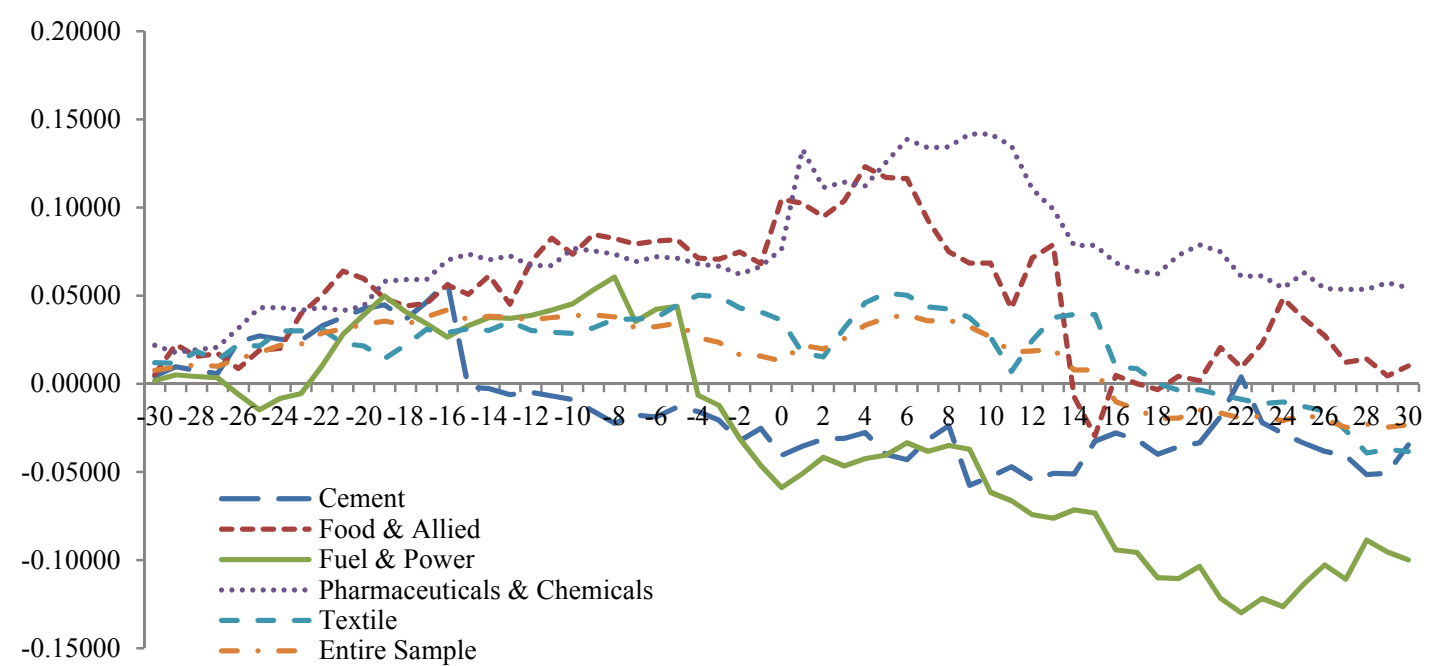

Figure 2. Sectoral decomposition of CAAR (T-30 to T+30)

Table 11 shows CAAR around the period of bonus issue announcement in Dhaka Stock Exchange (DSE). For the event windows $[-10,-1]$ and $[-5,-1]$ for the entire sample, the cumulative abnormal returns are significant at $1 \%$ which points to the fact that information leaks in DSE before announcement. However, for $[0,1],[0,5]$ and $[0$, 10] cumulative abnormal returns are also significant at $1 \%$ but increases which support existing theories that market reacts positively to the bonus issue announcement. Except for the Engineering sector, CAAR in the Cement, Food \& Allied, Fuel \& Power, Pharmaceuticals \& Chemicals and Textile sector for the event windows $[-10,-1]$ and $[-5,-1]$ is found statistically significant which can be interpreted as above that information in these sectors leak before the bonus share announcement.

In analyzing sector-wise CAAR for event window $[0,1],[0,5]$ and $[0,10]$, paradoxical results have been observed. For Food \& Allied, Pharmaceuticals \& Chemicals and Textile sector, for the above event windows, CAARs are significant at $1 \%$ and increases which support prevailing theories that market reacts positively to the stock dividend announcement. However, Engineering, Cement, Fuel \& Power sector for the same event windows, delivers CAARs which are statistically significant but decreases which challenges existing theories that market reacts positively to the stock dividend announcement.

Table 11. CAAR around the period of bonus issue announcement

\begin{tabular}{llllll}
\hline Event window periods & CAAR (-10,-1) & CAAR (-5,-1) & CAAR (0,1) & CAAR (0,5) & CAAR (0,10) \\
\hline \multirow{2}{*}{ Entire Sample } & 0.296 & 0.116 & 0.035 & 0.151 & 0.321 \\
& $(20.15)^{* * *}$ & $(10.72)^{* * *}$ & $(4.54)^{* * *}$ & $(12.86)^{* * *}$ & $(20.89)^{* * *}$ \\
Engineering & -0.051 & -0.075 & -0.064 & -0.116 & -0.136 \\
& $(-1.17)$ & $(-2.36)^{* *}$ & $(-2.85)^{* * *}$ & $(-3.36)^{* * *}$ & $(3.00)^{* * *}$ \\
Cement & -0.191 & -0.107 & -0.076 & -0.206 & -0.415 \\
& $(-5.179)^{* * *}$ & $(-3.95)^{* * *}$ & $(-3.95)^{* * *}$ & $(-7.02)^{* * *}$ & $(-10.79)^{* * *}$ \\
Food \& Allied & 0.768 & 0.367 & 0.207 & 0.646 & 1.067 \\
& $(24.72)^{* * *}$ & $(15.99)^{* * *}$ & $(12.76)^{* * *}$ & $(26.07)^{* * *}$ & $(32.89)^{* * *}$ \\
Fuel \& Power & 0.185 & -0.052 & -0.110 & -0.281 & -0.486 \\
Pharmaceuticals \& & $(6.63)^{* * *}$ & $(-2.52)^{* *}$ & $(-7.53)^{* * *}$ & $(-12.617)^{* * *}$ & $(-16.69)^{* * *}$ \\
Chemicals & 0.702 & 0.335 & 0.209 & 0.673 & 1.363 \\
Textile & $(35.34)^{* * *}$ & $(22.82)^{* * *}$ & $(20.20)^{* * *}$ & $(42.50)^{* * *}$ & $(65.75)^{* * *}$ \\
& 0.399 & 0.228 & 0.054 & 0.198 & 0.398 \\
\hline
\end{tabular}

$T$-values in parenthesis. $* * *$ indicates significant at 1 percent level. $* *$ indicates significant at 5 percent level.

\section{Conclusion}

This paper studies the stock price reaction to the announcement of bonus issues offered by different firms in Dhaka Stock Exchange (DSE) in Bangladesh. Sample in this paper includes all the 136 firms from six different sectors, i.e., Engineering, Cement, Food \& Allied, Fuel \& Power, Pharmaceuticals \& Chemicals, and Textile, which are listed on the Dhaka Stock Exchange (DSE) and also have declared stock dividend during 2009 to 2012. In the entire sample, significant price increase before and after the announcement date is detected which lends 
supports to the signaling hypothesis for Bangladesh. However, results also imply that the investors have anticipated the informational content of the event, or that they have gained access to inside information.

Conversely, sectoral decomposition of returns showed quite paradoxical results. Cement, Food \& Allied, Fuel \& Power, Pharmaceuticals \& Chemicals sector supports long-established theories that the stock market reacts positively to the announcement of a bonus issue. However, Engineering and Textile sector illustrates the opposite and thus supports Malhotra, Thenmozhi and Gopalaswamy (2012), Papaioannou, Travlos, and Tsangarakis (2000), and Dhatt, Kim and Mukherji (1997) results.

Given the size of the abnormal return, after making adjustments for transactions costs, generally speaking, it could be unrealistic for an investor in DSE to employ a strategy where she will buy only stocks in firms which announced bonus issue. Still results of the entire sample and also sectoral analysis raises serious questions against market efficiency and also theories that explain the phenomenon. It may be necessary to reinterpret the evidence in this paper.

However, it is important to mention that this study suffers from some limitations. For example, return, in this study, has not been adjusted for dividend. For few sectors, the sample size is quite small which could cause some unexpected result. For instance, Textile sector consists of 31 firms while Cement sector has only 16 firms. When firms release information about stock dividend, in many instance, they also discloses other material information which influence stock prices. However, in this paper, data has not been controlled for other simultaneous information release.

This study employs information of 136 right issues from 2009 to 2012. It worth mentioning that there was a massive market crash in Bangladesh in 2010 which hammered down the market return. Market was at its peak on December 5, 2010 when DGEN index was 8771. However, on July 18, 2013 the same index reached to 4568, i.e., 48 percent decline from the market peak. This extreme market crash could also impact our findings for this study. Using sample from a longer horizon could have smooth out the impact of market crash in 2010.

\section{Acknowledgments}

Financial support from the Independent University, Bangladesh (IUB) to conduct this research is sincerely acknowledged.

\section{References}

Adaoglu, C., \& Lasfer, M. A. (2011). Why do companies pay stock dividends? The case of bonus distributions in an inflationary environment. Journal of Business Finance \& Accounting, 38(5-6), 601-627. http://dx.doi.org/10.1111/j.1468-5957.2011.02233.x

Anderson, H., Cahan, S., \& Rose, L. C. (2001). Stock dividend in an imputation tax environment. Journal of Business Finance \& Accounting, 28(5), 653-669. http://dx.doi.org/10.1111/1468-5957.00388

Armitage, S. (1995). Event study methods and evidence on their performance. Journal of Economic Surveys, 8(4), 25-52. http://dx.doi.org/10.1111/j.1467-6419.1995.tb00109.x

Aydogan, K., \& Muradoglu, G. (1998). Do markets learn from experience? Price reaction to stock dividends in the Turkish market. Applied Financial Economics, 8(1), 41-49. http://dx.doi.org/10.1080/096031098333230

Balasingham, B., Faff, R., \& Tanner, S. (2004). Further evidence on the announcement effect of bonus shares in an imputation tax setting. Global Finance Journal, 15(2), 147-170. http://dx.doi.org/10.1016/j.gfj.2004.02.001

Ball, R., Brown, P., \& Finn, F. J. (1977). Share capitalisation changes, information and the Australian equity $\begin{array}{llll}\text { market. Australian Journal of } & \text { Management, }\end{array}$ http://dx.doi.org/10.1177/031289627700200202

Banker, R. D., Das, S., \& Datar, S. M. (1993). Complementary of prior accounting information: The case of stock dividend announcements. Accounting Review, 68(1), 28-47.

Barber, B. M., \& Lyon, J. D. (1997). Detecting long-run abnormal stock returns: The empirical power and specification of test statistics. Journal of Financial Economics, 43(3), 341-372. http://dx.doi.org/10.1016/S0304-405X(96)00890-2

Barnes, M. L., \& Ma, S. (2001). Market efficiency or not? The behaviour of China's stock prices in response to the announcement of bonus issues. Centre for International Economic Studies Discussion Paper No. 0120, Adelaide 
http://ro.uow.edu.au/cgi/viewcontent.cgi?article=1511\&context=commpapers

Bowman, R. G. (1983). Understanding and conducting event studies. Journal of Business Finance \& Accounting, 10(4), 561-584. http://dx.doi.org/10.1111/j.1468-5957.1983.tb00453.x

Brown, S. J., \& Warner, J. B. (1980). Measuring security price performance. Journal of Financial Economics, 8(3), 205-258. http://dx.doi.org/10.1016/0304-405X(80)90002-1

Brown, S., \& Warner, J. (1985). Using daily stock returns, the case of event studies. Journal of Financial Economics, 14(1), 3-31. http://dx.doi.org/10.1016/0304-405X(85)90042-X

Dhatt, M. S., Kim, Y. H., \& Mukherji, S. (1997). The role of stock dividends in Korea. Global Finance Journal, 8(2), 295-308. http://dx.doi.org/10.1016/S1044-0283(97)90021-1

Doran, D. T., \& Nachtmann, R. (1988). The association of stock distribution announcements and earnings performance. Journal of Accounting, Auditing \& Finance, 3(2), 113-132.

Eisemann, P. C., \& Moses, E. A. (1978). Stock dividends: Management's view. Financial Analysts Journal, 34(4), 77-80. http://dx.doi.org/10.2469/faj.v34.n4.77

Foster, T. W., \& Vickrey, D. (1978). The information content of stock dividend announcements. The Accounting Review, 53(2), 360-370.

Ghosh, C., \& Wooldridge, J. R. (1988). An analysis of shareholder reaction to dividend cuts and omissions. Journal of Financial Research, 9(11), 281-294.

Grinblatt, M., Masulis, R., \& Titman, S. (1984). The valuation effects of stock splits and stock dividends. Journal of Financial Economics, 13(4), 461-490. http://dx.doi.org/10.1016/0304-405X(84)90011-4

Healy, P. M., \& Palepu, K. G. (1988). Earnings information conveyed by dividend initiations and omissions. Journal of Financial Economics, 21(2), 149-175. http://dx.doi.org/10.1016/0304-405X(88)90059-1

Ikenberry, D., Rankine, G., \& Stice, L. (1996). What do stock splits really signal? Journal of Financial and Quantitative Analysis, 31(3), 357-375. http://dx.doi.org/10.2307/2331396

Kato, H. K., \& Tsay, W. (2002). Are stock dividends (MUSHOs) melons or lemons in Japan? Pacific-Basin Finance Journal, 10(5), 531-548. http://dx.doi.org/10.1016/S0927-538X(02)00041-0

Lakonishok, J., \& Lev, B. (1987). Stock splits and stock dividends: Why, who and when. Journal of Finance, 42(4), 913-932. http://dx.doi.org/10.1111/j.1540-6261.1987.tb03919.x

Lamoureux, C., \& Poon, P. (1987). The Market Reaction to Stock Splits. Journal of Finance, 42(5), 1347-1370. http://dx.doi.org/10.1111/j.1540-6261.1987.tb04370.x

Lijleblom, E. (1989). The informational impact of announcements of stock dividends and stock splits. Journal of Business Finance and Accounting, 16(5), 681-698. http://dx.doi.org/10.1111/j.1468-5957.1989.tb00047.x

Lyon, J. D., Barber, B. M., \& Tsai, C. (1999). Improved methods for tests of long-run abnormal stock returns. Journal of Finance, 54(1), 165-201. http://dx.doi.org/10.1111/0022-1082.00101

Malhotra, M., Thenmozhi, M., \& Gopalaswamy, A. K. (2012). Liquidity changes around bonus and rights issue announcements: Evidence from manufacturing and service sectors in India. International Journal of Money, Banking and Finance, 1(1), 28-34.

Marsh, P. (1979). Equity rights issues and the efficiency of the UK stock market. Journal of Finance, 34(4), 839-863. http://dx.doi.org/10.1111/j.1540-6261.1979.tb03439.x

Martikainen, T., Rothovlus, T., \& Yli-Olli, P. (1991). On the individual and incremental information content of accrual earnings, cash flows and cash dividends in the Finnish stock market. European Journal of Operational Research, 68(3), 318-333. http://dx.doi.org/10.1016/0377-2217(93)90188-S

Masse, I., Hanrahn, J. R., \& Kushner, J. (1997). The effect of Canadian stock splits, stock dividends and reverse splits on the value of the firm. Quarterly Journal of Business and Economics, 36(4), 51-62.

McNichols, M., \& Dravid, A. (1990). Stock dividends, stock splits and signaling. Journal of Finance, 45(3), 857-879. http://dx.doi.org/10.1111/j.1540-6261.1990.tb05109.x

Miller, M., \& Modigliani, F. (1961). Dividend policy, growth and the valuation of shares. Journal of Business, 34(4), 411-433. http://dx.doi.org/10.1086/294442

Mishra, A. K. (2005). An empirical analysis of market reaction around the bonus issues in India. The ICFAI Journal of Applied Finance, 11(7), 21-39. 
Obaidullah, M. (1992). How do stock prices react to bonus issues? Vikalpa, 17(1), 17-22.

Papaioannou, G. J., Travlos, N. G., \& Tsangarakis, N. V. (2000). Valuation effects of Greek stock dividend distributions. European Financial Management, 6(4), 515-531. http://dx.doi.org/10.1111/1468-036X.00137

Pathirawasam, C. (2009). The information content of stock dividend announcements: Evidence from Sri Lanka. Ekonomická Revue-Central European Review of Economic Issues, 12(3), 103-114. http://dx.doi.org/10.7327/cerei.2009.09.01

Peterson, R. (1971). Bonus issues, share issues, share splits and rights issues. The Chartered Secretary, 198-207.

Ramachandran, J. (1985). Behavior of stock market prices, trading rules, information \& market efficiency. Doctoral Dissertation, Indian Institute of Management, Ahmadabad.

Rao, C. K., \& Geetha, T. (1996). Indian Capital Market (Informational Signaling and Efficiency). New Delhi: Publishing Corporation.

Rao, S. N. (1994). The adjustment of stock prices to corporate financial policy announcements. Finance India, 8(4), 941-953.

Rao, S. N., \& Lukose, P. J. J. (2005). Does bonus issues signal superior performance? A study of the BSE listed firms. Decision, 32(1), 39-64.

Ritter, J. (1991). The long-term performance of initial public offerings. Journal of Finance, 46(1), 3-27. http://dx.doi.org/10.1111/j.1540-6261.1991.tb03743.x

Sharpe, W. F. (1963). A simplified model for portfolio analysis. Management Science, 9(2), 277-293. http://dx.doi.org/10.1287/mnsc.9.2.277

Sloan, R. G. (1987). Bonus issues, share splits and ex-day share price behaviour: Australian evidence. Australian Journal of Management, 12(2), 277-291. http://dx.doi.org/10.1177/031289628701200208

Travlos, N., Trigeorgis, L., \& Vafeas, N. (2001). Shareholder wealth effects of dividend policy changes in an emerging stock market: The case of Cyprus. Multinational Finance Journal, 5(2), 87-112.

Wooldridge, J. R. (1983). Stock dividends as signals. Journal of Financial Research, 6(1), 1-12.

\section{Copyrights}

Copyright for this article is retained by the author(s), with first publication rights granted to the journal.

This is an open-access article distributed under the terms and conditions of the Creative Commons Attribution license (http://creativecommons.org/licenses/by/3.0/). 